\title{
School Culture and Teachers' Work Values
}

\author{
Nilda V. San Miguel ${ }^{\mathrm{a}}$, Elymar A. Pascual ${ }^{\mathrm{b}}$ \\ elymarpascual@rocketmail.com \\ ${ }^{a}$ Department of Education, Lumban District, Lumban Laguna, Philippines, 4014 \\ ${ }^{\mathrm{b}}$ Deparment of Education, Nagcarlan District, Nagcarlan, Laguna, Philippines, 4002
}

\begin{abstract}
This study focused on determining the effect of the awareness of school culture to the work values of the teachers in Masapang Elementary School, Victoria, Laguna, school year 2018-2019. School culture cannot be easily changed over a period of time. It is already part of the daily routine of the people moving inside the school - teachers, learners and stakeholders. But having the awareness of the different school culture is something that the researcher investigated, whether or not it affects the teachers' work values. This study went on a quantitative design in doing an action research. Twenty elementary teachers became the respondent of this study. The school head, which is also one of the researchers, introduced a 45-item work values survey and 40-item school culture survey to determine the work characteristics of teachers and their perception of school culture. Then the researchers conducted a series of school learning action cell (SLAC) that centered on the discussion of different school culture in four dimensions - individualismcollectivism, power distance, uncertainty avoidance, and masculinity-femininity. To find out if their work values changed, a post survey was conducted. Data was recorded and processed. It was found out that work values significantly increased after the conduct of School Learning Action Cells. Specifically, 8 attributes of work values out of 15 had significant increase - management, surroundings, associates, aesthetics, prestige, independence, variety, and economic return. Recommendations to school heads, teachers, community officials and future researchers were given at the end of the study.
\end{abstract}

Keywords: school culture; work values; individualism; collectivism; power distance; aggresivism; fatalism; masculine; feminine

\section{Introduction}

Quality education is a vital factor in the life-long learning of an individual; thus helping them acquire a better academic life and build better communications. Educational leaders and teachers greatly contribute in acquiring quality education. Further, positive school cultural values can produce competent teachers having high performance rate.

It is the culture that dictates how the people in a specific environment communicate with each other, deal with each other, and treat each other. It is not developed in a single moment in time when a group agrees with each other on certain norms, but is formed intentionally or unintentionally over a period of time, and is transferred from one generation to another. The leaders play an important role and are responsible in relaying the type of culture that he wants to develop within his premise. At the same time, the members or subordinates should cooperate in order for the prescribed norm to be realized.

The same thing happens in a school institution. The leader sets up the culture that he wants to implement as he lives up with the mission and vision and attains the objectives. The teachers, even the parents and students, display this culture that enables the institution to have an instinctive identity and allows them to 
attract clients. This culture stays as long as the leader remains, or is consistent with the culture that he wants to project. On the other hand, when one is not able to adapt to the culture, the person becomes alienated, but sooner or later learns to adjust because many persons are doing so.

Work value is another factor that has something to do with the operation of the school. It can be divided into fifteen different attributes - creativity, management, achievement, surroundings, supervisory relations, way of life, security, associates, aesthetics, prestige, independence, variety, economic return, altruism, and intellectual stimulation. With these in mind, the question arises. Can the knowledge or awareness of the different school culture affect the level of work values of elementary school teachers?

\subsection{Background of the Study}

Masapang Elementary School has been established since 1969. For 49 years, it has been known to produce quality graduates, including public servant Bert Lina. The school follows the mandate of Article XIV Section 1 of the 1987 Philippine Constitution which declares that the State shall protect and promote the right of every citizen to quality basic education and to make such education accessible to all. Together with the task of providing the basic educational needs, the school is facing the biggest challenge of having quality and excellence both on the educational services and among the graduates this educational institution has produced.

It is a usual notion that the environment where an individual thrive contributes much to the behavior of an individual. Take for example the basic institution, the family. If the family has a close relationship and spends quality time with each other, the children grow with respect and cooperation. On the other hand, if the family misses some quality time and the members spend most of their time outside the house, the children grow with hostility and disrespect. This is parallel to the children's second home, the school. The culture in school inculcates behavior that the students learn everyday of their stay in school. The effect does not only permeate to the pupils or students, but to the teachers as well. This is the primary reason why the researcher decided to look at the issue of the school cultural values.

Yearly evaluation has become part of the routine so as to ensure that quality education is being delivered to the Filipino children. Also, this evaluation serves as a performance basis for those seeking for promotion. Added to the performance of the teacher inside the school are his or her work values. Several studies have highlighted the effect of work values to teachers' performance. But there is no study broadcasted that looked into the effect of awareness of school culture to teachers' work values. And so, this study is conducted.

\subsection{Theoretical Background}

In the book Organizational Behavior and Management by Ivancevich and Matteson (2005), four dimensions of cultural values are mentioned, as shown in Table 1.

Table 1. School cultural values

\begin{tabular}{|l|l|l|l|l|}
\hline \multicolumn{2}{|c|}{ Hofstede's Dimensions } \\
\hline $\begin{array}{l}\text { Region/ } \\
\text { Country }\end{array}$ & $\begin{array}{l}\text { Individualism- } \\
\text { Collectivism }\end{array}$ & Power Distance & $\begin{array}{l}\text { Uncertainty } \\
\text { Avoidance }\end{array}$ & $\begin{array}{l}\text { Masculinity- } \\
\text { Femininity }\end{array}$ \\
\hline North America (USA) & Individualism & Low & Medium & Masculine \\
\hline Japan & Collectivism & High and low & High & $\begin{array}{l}\text { Masculine and } \\
\text { feminine }\end{array}$ \\
\hline
\end{tabular}




\begin{tabular}{|l|l|l|l|l|}
\hline Europe & Individualism & Low/medium & Low/medium & Masculine \\
\hline $\begin{array}{l}\text { Anglo Germanic West } \\
\text { Slavic and West Urgic }\end{array}$ & Medium individualism & Low & Medium/low & $\begin{array}{l}\text { Medium/ high } \\
\text { masculine }\end{array}$ \\
\hline Near Eastern Balkanic & Collectivism & High & High & Medium masculine \\
\hline Nordic & $\begin{array}{l}\text { Medium/high } \\
\text { individualism }\end{array}$ & Low & Low/medium & Feminine \\
\hline Latin Europe & $\begin{array}{l}\text { Medium/high } \\
\text { individualism }\end{array}$ & High & High & Medium masculine \\
\hline East Slavic & Collectivism & Low & Medium & Masculine \\
\hline China & Collectivism & Low & Low & $\begin{array}{l}\text { Masculine and } \\
\text { Feminine }\end{array}$ \\
\hline Africa & Collectivism & High & High & Feminine \\
\hline Latin America & Collectivism & High & High & Masculine \\
\hline
\end{tabular}

The first dimension of culture aspect is individualism-collectivism. The culture of an organization may either be promoting self-growth and individual advancement contributing to the whole, or group effort and togetherness in meeting the objectives. The countries exercising individualism are North America, Europe, Anglo Germanic West Slavic and West Urgic, Nordic, and Latin Europe. On the other hand, the countries exercising collectivism are Japan, Near Eastern Balkanic, East Slavic, China, Africa, and Latin America.

The second dimension of culture is power distance. The school may either be operating on a high power distance where the hierarchy is vertical and the relationship of superiors and subordinates needs channel, or low power distance where the hierarchy is flat and there is a holistic relationship. The countries operating on high power distance are Near Eastern Balkanic, Latin Europe, Africa and Latin America. On the other hand, the countries operating on low power distance are North America, Europe, Anglo Germanic West Slavic and West Urgic, Nordic, East Slavic and China. Japan's culture of power distance depends on the masculinity or femininity of culture. If the leader is masculine, then there is a high power distance, and if the leader is feminine, the power distance is low.

The third dimension is uncertainty avoidance. An organization may either have high uncertainty avoidance concept where risk-taking is not part of planning but is detailed, cautious and specific; or low uncertainty avoidance where risk-taking is part of planning and there is the organization is pro-active. The countries who have a concept of high uncertainty avoidance are Japan, Near Easter Balkanic, Latin Europe, Africa and Latin America. On the other hand, the countries who have a concept of low uncertainty avoidance are Europe, Nordic, and China. There are also those whose uncertainty avoidance are medium - North America, Anglo Germanic West Slavic and West Urgic, and East Slavic.

The last dimension of culture is masculinity-femininity. The culture of an organization may be influenced by male gender because the leaders arising are male, or it can be influenced by female gender because the leaders arising are female. The countries with a masculine inclination in their leadership are North America, Anglo Germanic West Slavic and West Urgic, Near Eastern Balkanic, Latin Europe, East Slavic, and Latin America. On the other hand, the countries with a feminine inclination in their leadership are Nordic and Africa. There are also those with an inclination of both - Japan and China. 


\subsection{Conceptual Background}

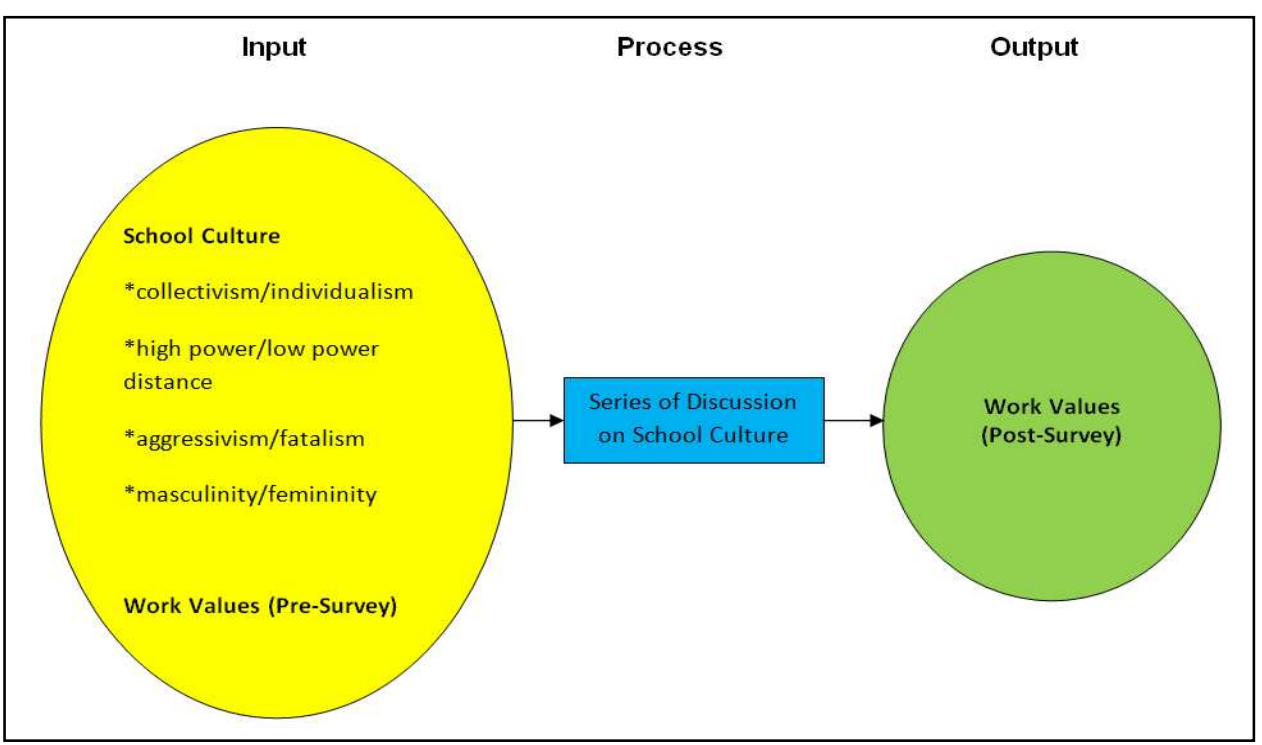

Fig. 1. The input-process-output framework

The figure above highlights the framework for this study. The Input contains the school culture which has four dimensions - collectivism/individualism, high power/low power distance, aggresivism/fatalism, and masculinity/femininity. It also contains the work values which is recorded as a presurvey. The Process is consists solely of series of discussion on school culture. While the Output comprises the work values which is a post survey after the series of discussion on school culture.

\subsection{Statement of the Problems}

This study focused on investigating the effect of awareness to school culture to teachers' work values in Masapang Elementary School, school year 2018-2019.

Specifically, it sought to answer the following questions:

1. What is the mean level of work values of the teachers in Masapang Elementary School before the

SLACs in terms of the following:
a. creativity;
b. management;
c. achievement;
d. surroundings;
e. supervisory relations;
f. way of life;
g. security;
h. associates;
i. aesthetics;
j. prestige; 

k. independence;
1. variety;
m. economic return;
n. altruism; and
o. intellectual stimulation

2. What is the status of teachers' perception of school culture in terms of the following:

a. individualism-collectivism;

b. power distance;

c. uncertainty avoidance; and

d. masculinity-femininity

3. What is the status of the conduct of School Learning Action Cells (SLACs) with regards to school culture?

4. What is the mean level of work values of teachers in terms of the fifteen indicators after the SLACs?

5. Does the conduct of SLACs significantly affect the work values of teachers?

\subsection{Hypothesis}

The tentative solution to the problem posted above is this:

"The conduct of School Learning Action Cells does not affect the work values of teachers in Masapang Elementary School."

\subsection{Scope and Limitation}

This study operates on the context that the conduct of SLAC may or may not affect the work values of teachers. It does not suggest change of school culture after the SLAC because in every dimension of school culture, there is a negative and positive implication, thus, communicating the baseline idea that there is no best school culture. While school culture cannot be changed over a short period of time, work values can. The series of mini-SLACs that have been conducted covers only a period of one month, that is, one session per week, covering the four dimensions of school culture.

\section{Related Literature}

Organizational culture has many forms or types. It can be an open culture or close culture. Open culture operates on holistic relationship where the leader is seen to easily mingle with subordinates. It encourages risk taking, initiative attitude, volunteerism, collectivism and collaboration. On the other hand, close culture operates with limited relationship, little risk taking, individualism and strict policy implementation. While open culture is more of people oriented, close culture is task oriented.

Pang's (2008) studied bureaucratic and cultural linkage as well as tight and loose coupling of schools since these represent several approaches to coordinating and directing staff activities. Tight coupling referred to 'coupling' teaching staff using clear goal orientation and communication and consensus among staff. Loose coupling emphasized a professional orientation and teacher autonomy. Further, bureaucratic linkage reflected formal means of coordination, like formality, bureaucratic control and rationality, while cultural linkage referred to informal approaches, like participation and collaboration, collegiality and achievement orientation. Pang's study showed that for the excellent schools in his sample "emphases on cultural linkage and loose coupling were the most consistent strategies ... tight coupling the next, but emphasis on bureaucratic linkage was quite diverse". He concludes that the first three are strong forces that bind people together within schools, 
while such an effect was not apparent for bureaucratic linkage. Despite this research, the empirical evidence for a relationship between organizational culture and school effectiveness is still rather weak. This is caused, to some extent, by the fact that various conceptualization and operationalization of school culture were used in the aforementioned studies.

Cohen's (2009) article about challenge of assessing educational climate towards leadership posed the issue on looking deep into the school culture that may affect school performance.

According to Smith (2012) teachers will reflect on their behavior and become conscious of the basic assumptions that underpin their interpretation of what they do. Basic assumptions are often operationalized into five groups: the organization's relationship to its environment, the nature of reality and truth, the nature of human nature, the nature of human activity and the nature of human relationships. These dimensions reflect the fundamental questions people face. For instance, the nature of human nature refers to whether humans are essentially 'bad' or 'good', and whether humans are basically "fixed at birth", or whether they are "mutable and perfectible". The second level consists of values and norms. Values refer to what teachers belief is 'good', 'right' or 'desirable'. Values, therefore, are to be considered as standards of desirability; they reflect what is conceived to be important to pursue or worth striving for in school .Teachers, for instance, may consider respect for others important, or may value collaboration with other staff members.

Collectivism is a social act that originated in company setting where laborers act as a group in dealing with the administration. Through the years, this social act become popular in school setting. In study made by Atienza (2009), she found out that there is a collectivism culture in the schools where she conducted research. Teachers often consult parents, hold meetings and regular dialogues, guides and support the programs, and join the formulation of different activities for ht enhancement of learning. Parents also involve themselves in the school activities. Teacher-parent rapport significantly affect the scholastic performance of the pupils. This clearly shows collectivism on the part of the parents and teachers. The study of Atienza (2009) supports the study of Dela Viña (2007) which concludes that there is a significant effect of the coordination among principals, teachers and parents to school performance.

On the other hand, DepEd Order No. 35, s. 2015, The Learning Action Cell (LAC) as a K to 12 Basic Education Program, highlights the conduct of school-based sessions for the continuing professional development and for the improvement of teaching and learning.

The above-mentioned readings shed light on this study because they have highlighted on the concept of school culture and other related issues.

\section{Research Design}

This study made use of an experimental method in its proceedings. According to Caraan, Jr. (2011), experimental method has something to do with a conduct of experiment, and it has become a viable method in advancing scientific studies. In this paper, the experiment is the conduct of a School Learning Action Cells (SLAC), with the researcher discussing the different dimensions of school culture to the teachers. Through this experiment of holding the teachers to complete interest or attention to the different cultures of an organization, the researcher investigated on the change of their work values over a period of time.

\subsection{Population}

Masapang Elementary School has a teacher-workforce of 21. They had become the respondent for this study. The table on the next page shows the breakdown in terms of their position. 
Table 2. Respondents of the study

\begin{tabular}{|l|c|}
\hline \multicolumn{1}{|c|}{ Position } & Frequency \\
\hline Teacher I & 10 \\
\hline Teacher II & 2 \\
\hline Teacher III & 7 \\
\hline Master Teacher I $\quad$ Total & 1 \\
\hline \multicolumn{2}{|c|}{$\mathbf{2 0}$} \\
\hline
\end{tabular}

\subsection{Data Gathering Procedure}

This research passed through ethical consideration by asking first for the permission of the District Supervisor if he would allow the study. The flowchart on the next page shows the procedure followed in gathering data that would answer the problems posted at the beginning of the study.

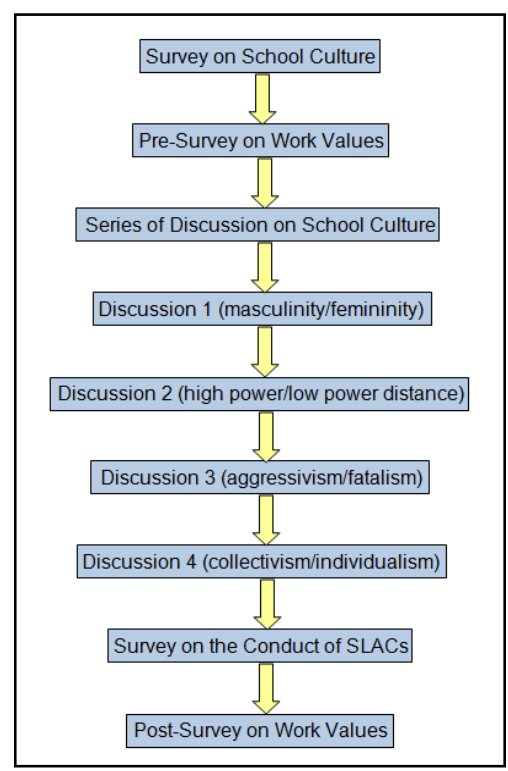

Fig. 2. Steps undertaken in gathering data

This flowchart showcases the path followed in gathering data that will answer the questions posted at the beginning of the study.

\section{Presentation, Interpretation and Analysis of Data}

This part showcases the presentation, analysis and interpretation of result that came out of the proceedings of this study. 
Table 3. Teacher's work value before the SLAC on school culture

\begin{tabular}{|c|c|c|c|c|}
\hline \multicolumn{2}{|r|}{ Attributes } & Mean & SD & Interpretation \\
\hline \multicolumn{2}{|c|}{ 1. Creativity } & 4.39 & 0.17 & Very High Level \\
\hline \multicolumn{2}{|c|}{ 2. Management } & 3.86 & 0.63 & High Level \\
\hline \multicolumn{2}{|c|}{ 3. Achievement } & 4.41 & 0.06 & Very High Level \\
\hline \multicolumn{2}{|c|}{ 4. Surroundings } & 4.37 & 0.14 & Very High Level \\
\hline \multicolumn{2}{|c|}{ 5. Supervisory relations } & 4.67 & 0.03 & Very High Level \\
\hline \multicolumn{2}{|c|}{ 6. Way of life } & 4.37 & 0.19 & Very High Level \\
\hline \multicolumn{2}{|c|}{ 7. Security } & 4.22 & 0.09 & Very High Level \\
\hline \multicolumn{2}{|c|}{ 8. Associates } & 4.20 & 0.43 & High Level \\
\hline \multicolumn{2}{|c|}{ 9. Aesthetics } & 4.25 & 0.09 & Very High Level \\
\hline \multicolumn{2}{|c|}{ 10. Prestige } & 4.16 & 0.29 & High Level \\
\hline \multicolumn{2}{|c|}{ 11. Independence } & 4.08 & 0.38 & High Level \\
\hline \multicolumn{2}{|c|}{ 12. Variety } & 4.18 & 0.06 & High Level \\
\hline \multicolumn{2}{|c|}{ 13. Economic return } & 4.14 & 0.07 & High Level \\
\hline \multicolumn{2}{|c|}{ 14. Altruism } & 4.51 & 0.07 & Very High Level \\
\hline \multicolumn{2}{|c|}{ 15.Intellectual stimulation } & 4.49 & 0.12 & Very High Level \\
\hline & Average & 4.29 & 0.19 & Very High Level \\
\hline \multirow[t]{5}{*}{ Legend: } & $4.21-5.00$ & & & \\
\hline & $3.41-4.20$ & & & \\
\hline & $2.61-3.40$ & & & \\
\hline & $1.81-2.60$ & & & \\
\hline & $1.00-1.80$ & & & \\
\hline
\end{tabular}

The table above shows the work values of the faculty of Masapang Elementary School in fifteen indicators. Teachers have a very high level of work values in terms of nine indicators - creativity, achievement, surroundings, supervisory relations, way of life, security, aesthetics, altruism and intellectual stimulation. On the other hand, they have a high level of work values in terms of six attributes - management, associates, prestige, independence, variety and economic return. All the attributes have a standard deviation of less than one, indicating that the teacher have homogenous answers.

Considering those attributes that attained very high level, six can be considered personal or those that does not concern relation to others, and they are creativity, achievement, way of life, security, aesthetics and intellectual stimulation. This may be the reason why they were able to rate these attributes very high level for themselves. The other three has something to do with others - surroundings, supervisory relations and altruism. These three attained very high level of ratings from teachers, showing that the latter have the ability to easily adapt with their colleagues at work, and has matured emotional quotient of having concern with others. 
Going over the six attributes that gained high level of ratings, three can be considered of personal issue - prestige, economic return and independence. These did not gained very high level, probably because the first two concerns financial, while the third one speaks of the attitude of teachers to mingle with others and to depend on them sometimes in matters of decision in school work. The rest of the three concerns relations to others - management, associates and variety. Teachers did not gained very high level on these areas probably because they still has issues on management or the system that easily changes over time.

The table below shows the culture where Masapang Elementary Operates. On a fast glimpse, it can be seen that the school operates on the culture of collectivism, low power distance, aggressivism, and feminine. All of these are concluded because these cultures gained a higher mean level over the other cultures, as perceived by the teachers. The standard deviation of less than one, or a little bit higher than one, shows the homogeneity of the answers of the respondents.

Table 4. Perception on school culture

\begin{tabular}{|c|c|c|c|c|}
\hline \multicolumn{2}{|c|}{ Dimensions } & Mean & SD & Interpretation \\
\hline \multirow{2}{*}{$\begin{array}{c}\text { Individualism- } \\
\text { Collectivism }\end{array}$} & Individualist & 4.16 & 0.36 & \multirow{2}{*}{$\begin{array}{c}\text { The school operates on } \\
\text { collectivist culture. }\end{array}$} \\
\hline & Collectivist & 4.24 & 0.40 & \\
\hline \multirow{2}{*}{ Power Distance } & Low Power Distance & 4.34 & 0.34 & \multirow{2}{*}{$\begin{array}{c}\text { The school operates on } \\
\text { low power distance } \\
\text { culture. }\end{array}$} \\
\hline & High Power Distance & 4.05 & 0.56 & \\
\hline \multirow{2}{*}{ Uncertainty Avoidance } & Aggressivist & 3.99 & 0.51 & \multirow{2}{*}{$\begin{array}{c}\text { The school operates on } \\
\text { aggresivist culture. }\end{array}$} \\
\hline & Fatalist & 3.96 & 0.37 & \\
\hline \multirow{2}{*}{$\begin{array}{l}\text { Masculinity- } \\
\text { Femininity }\end{array}$} & Masculine & 3.34 & 1.05 & \multirow{2}{*}{$\begin{array}{c}\text { The school operates on } \\
\text { feminine culture. }\end{array}$} \\
\hline & Feminine & 3.60 & 0.92 & \\
\hline
\end{tabular}

The school, operating on collectivism culture, means that they proceed as a group every time there is a project or program to accomplish. There might be division of labor but the solidarity in doing a task still remains. Working hand-in-hand is a good habit that gives encouragement to others, especially those who are weak or works on a slower pace.

Masapang Elementary School has a low power distance. Teachers can go directly to the school head without any more consenting with the department heads. The organization is flat. Communication is fast. There are few heads to obey. Leadership resides on few, or sole authority.

Aggresivism prevails also in Masapang Elementary School. Teachers and school head do not want to settle to what have been accustomed. They want to experiment on new methods or strategies, new projects and programs, new ways of getting into their target. This does not mean forgetting the old ones, but just experimenting on new ways that might be easy with the old ones.

Feminine culture also permeates. Care and welfare of the workforce is of higher importance than development. Female voices are more heard than male ones. This does not mean that male ideas are not heard. It just mean that female ideas most of the time prevails, not because of numbers, but probably because of having matured female members over younger male ones.

The table in the next page shows the teachers' rating on the conduct of SLACs that deals with the dimensions of school culture. It can be seen that indicators number 1, 2, 3, 4, 6, 9 and 10 gained a rating of very highly satisfactory. These indicators are the ones that pertain to the mastery and confidence of the speakers (the researchers themselves), confidence, the good flow of discussion, and the level on how the teachers would like the SLACs to be shared also to other schools. On the other hand, indicators numbers 5, 7 and 8 gained a rating of highly satisfactory. These are items that pertain to the venue, the cooperation of 
participants, and the manner on how they perceive the topic of SLACs as helpful in the educative process.

Table 5. Status of the Conduct of School Learning Action Cells (SLACs)

\begin{tabular}{|c|c|c|c|c|}
\hline \multicolumn{2}{|c|}{ Indicators } & Mean & SD & Interpretation \\
\hline \multicolumn{2}{|c|}{ 1. The SLAC was conducted on a convenient time without the disruption of classes. } & 4.46 & 0.71 & $\begin{array}{l}\text { Very Highly } \\
\text { Satisfactory }\end{array}$ \\
\hline \multicolumn{2}{|c|}{ 2. The SLAC went well and everyone understands the topic discussed. } & 4.32 & 0.43 & $\begin{array}{l}\text { Very Highly } \\
\text { Satisfactory }\end{array}$ \\
\hline \multicolumn{2}{|r|}{$\begin{array}{l}\text { 3. The ideas presented in the SLAC are issues or topic that can help teachers grow in } \\
\text { their relationship with other teachers. }\end{array}$} & 4.57 & 0.42 & $\begin{array}{l}\text { Very Highly } \\
\text { Satisfactory }\end{array}$ \\
\hline \multicolumn{2}{|c|}{ 4. The speaker/researcher answered questions politely and clearly. } & 4.72 & 0.67 & $\begin{array}{l}\text { Very Highly } \\
\text { Satisfactory }\end{array}$ \\
\hline \multicolumn{2}{|c|}{ 5. The venue of the SLAC was comfortable. } & 4.07 & 0.92 & Highly Satisfactory \\
\hline \multicolumn{2}{|c|}{ 6. The SLAC became an avenue for clearing things with regards to the topic. } & 4.60 & 0.32 & $\begin{array}{l}\text { Very Highly } \\
\text { Satisfactory }\end{array}$ \\
\hline \multicolumn{2}{|c|}{$\begin{array}{l}\text { 7. The SLAC is academic in nature and provides information that is necessary for } \\
\text { educative process. }\end{array}$} & 4.11 & 0.55 & Highly Satisfactory \\
\hline \multicolumn{2}{|r|}{ 8. Other attendees of the SLAC are cooperative and willing to accept ideas from others. } & 4.03 & 0.40 & Highly Satisfactory \\
\hline \multicolumn{2}{|r|}{$\begin{array}{l}\text { 9. The speaker/researcher has a mastery of the topic and was able to deliver the } \\
\text { information with confidence. }\end{array}$} & 4.67 & 0.81 & $\begin{array}{l}\text { Very Highly } \\
\text { Satisfactory }\end{array}$ \\
\hline \multicolumn{2}{|c|}{ 10. The SLAC can be shared to other school because the topic is interesting. } & 4.71 & 0.39 & $\begin{array}{l}\text { Very Highly } \\
\text { Satisfactory }\end{array}$ \\
\hline & Average & 4.43 & 0.56 & $\begin{array}{l}\text { Very Highly } \\
\text { Satisfactory }\end{array}$ \\
\hline \multirow[t]{5}{*}{ Legend: } & Very Highly Satisfactory & & & \\
\hline & Highly Satisfactory & & & \\
\hline & Satisfactory & & & \\
\hline & Fairly Satisfactory & & & \\
\hline & Unsatisfactory & & & \\
\hline
\end{tabular}

The table in the next page shows the level of work values of the 20 teachers in Masapang Elementary School, with the 15 attributes of working having individual summary of rating. All attributes, except attribute number 2 which is management, gained a rating of very high level. The teachers can be considered to have a mature level of work values because they are considered professional and they are guided with the code of ethics for professional teachers. The attribute management may have only a high level probably because they still have questions or issues with regards to management which cannot be dealt with in one sitting, especially when those issues have connection to higher level of management which the school system cannot solve. 
Table 6. Teacher's Work Value After the SLACs on School Culture

\begin{tabular}{|c|c|c|c|c|}
\hline \multicolumn{2}{|r|}{ Attributes } & Mean & SD & Interpretation \\
\hline \multicolumn{2}{|c|}{ 1. Creativity } & 4.43 & 0.14 & Very High Level \\
\hline \multicolumn{2}{|c|}{ 2. Management } & 4.14 & 0.39 & High Level \\
\hline \multicolumn{2}{|c|}{ 3. Achievement } & 4.47 & 0.00 & Very High Level \\
\hline \multicolumn{2}{|c|}{ 4. Surroundings } & 4.49 & 0.07 & Very High Level \\
\hline \multicolumn{2}{|c|}{ 5. Supervisory relations } & 4.67 & 0.03 & Very High Level \\
\hline \multicolumn{2}{|c|}{ 6. Way of life } & 4.41 & 0.16 & Very High Level \\
\hline \multicolumn{2}{|c|}{ 7. Security } & 4.31 & 0.14 & Very High Level \\
\hline \multicolumn{2}{|c|}{ 8. Associates } & 4.35 & 0.26 & Very High Level \\
\hline \multicolumn{2}{|c|}{ 9. Aesthetics } & 4.35 & 0.06 & Very High Level \\
\hline \multicolumn{2}{|c|}{ 10. Prestige } & 4.29 & 0.20 & Very High Level \\
\hline \multicolumn{2}{|c|}{ 11. Independence } & 4.25 & 0.33 & Very High Level \\
\hline \multicolumn{2}{|c|}{ 12. Variety } & 4.29 & 0.10 & Very High Level \\
\hline \multicolumn{2}{|c|}{ 13. Economic return } & 4.27 & 0.03 & Very High Level \\
\hline \multicolumn{2}{|c|}{ 14. Altruism } & 4.51 & 0.07 & Very High Level \\
\hline \multicolumn{2}{|c|}{ 15.Intellectual stimulation } & 4.53 & 0.06 & Very High Level \\
\hline & Average & 4.39 & 0.14 & Very High Level \\
\hline \multirow[t]{5}{*}{ Legend: } & $4.21-5.00$ & & & \\
\hline & $3.41-4.20$ & & & \\
\hline & $2.61-3.40$ & & & \\
\hline & $1.81-2.60$ & & & \\
\hline & $1.00-1.80$ & & & \\
\hline
\end{tabular}

The table in the next page shows the paired t-test result of level of works values before and after the conduct of series of SLAC on dimensions of school culture. It can be seen that 8 out of 15 attributes increased significantly, as shown by greater $\mathrm{t}$-computed compared to t-tabular. These attributes that increased significantly are management, surroundings, associates, aesthetics, prestige, independence, variety and economic return. The significant increase is supported by P-values which are lower than the alpha level 0.05 . This means that with $95 \%$ confidence, it can be said that the conduct of SLACs which gives awareness on the dimensions of school culture helped increased teachers' work values. 
Table 7. T-test of Paired Samples for the Significant Effect of SLAC to Work Values

\begin{tabular}{|l|c|c|c|c|c|c|}
\hline \multicolumn{1}{|c|}{ Attributes } & $\begin{array}{c}\text { Mean Before } \\
\text { SLACs }\end{array}$ & $\begin{array}{c}\text { Mean After } \\
\text { SLACs }\end{array}$ & T-comp & T-crit & P-value & Significance \\
\hline 1. Creativity & 4.39 & 4.43 & 0.69 & 2.09 & 0.69 & \\
\hline 2. Management & 3.86 & 4.14 & 2.42 & 2.09 & 0.02 & Significant \\
\hline 3. Achievement & 4.41 & 4.47 & 0.47 & 2.09 & 0.83 & \\
\hline 4. Surroundings & 4.37 & 4.49 & 2.20 & 2.09 & 0.04 & Significant \\
\hline 5. Supervisory relations & 4.67 & 4.67 & 1.45 & 2.09 & 0.58 & \\
\hline 6. Way of life & 4.37 & 4.41 & 0.69 & 2.09 & 0.69 & \\
\hline 7. Security & 4.22 & 4.31 & 0.14 & 2.09 & 0.90 & Significant \\
\hline 8. Associates & 4.20 & 4.35 & 2.31 & 2.09 & 0.03 & Significant \\
\hline 9. Aesthetics & 4.25 & 4.35 & 2.20 & 2.09 & 0.04 & Significant \\
\hline 10. Prestige & 4.16 & 4.29 & 2.20 & 2.09 & 0.04 & Significant \\
\hline 11. Independence & 4.08 & 4.25 & 2.31 & 2.09 & 0.03 & Significant \\
\hline 12. Variety & 4.18 & 4.29 & 2.31 & 2.09 & 0.04 & Significant \\
\hline 13. Economic return & 4.14 & 4.27 & 2.31 & 2.09 & 0.04 & \\
\hline 14. Altruism & 4.51 & 4.51 & 1.45 & 2.09 & 0.57 & \\
\hline 15.Intellectual & 4.53 & 0.69 & 2.09 & 0.68 & \\
stimulation & 4.49 & & & & &
\end{tabular}

alpha $=0.05$

On the other hand, there are 7 attributes of work values that increased in level, but the increase is significant. These attributes are creativity, achievement, supervisory relations, way of life, security, altruism and intellectual stimulation.

The result in this study can be given light by what Smith (2012) declared in his writings, that teachers reflect on their behaviour and become conscious of the basic assumptions that underpin their interpretation of what they do. Because of the conduct of SLACs, they became aware that there are indeed different school culture, and that each culture has its own strengths and weakness. Therefore, teachers need not to look for their desired culture, because it is created over a long period of time and it depends on the totality of people contributing in a group or community or congregation.

\section{Recommendation and Reflection}

\subsection{Recommendation}

Based on the result the came out of this study, the following recommendation is given to the target person or group of persons:

- School heads should conduct regular assessment of school climate so as to adapt projects and programs that will suit the kind of community a school builds.

- Teachers should always seek not just professional growth but also personal growth because work values are very important in having a good performance in a workplace.

- Community officials should seek opportunities to support school activities, and not just wait for call assistance for specific projects. They need to be active in supporting school objectives for the benefit of the learners.

- Future researchers can include other factors that can help increase work values of teachers, such as 
seminars, workshops and other related activities.

\subsection{Reflection}

The conduct of this study opened the eyes of the researchers about the school culture of Masapang Elementary School. Through this, school governance will somehow have means of direction. Relationship with subordinates will not anymore created skirmishes, or if not totally abolished as is normal in an organization, the struggles in association will be decreased.

Also, as this study revealed that work values increased through the dissemination of information on school culture, the researchers were delighted to the fact that work values can be increased if teachers will have a thorough knowledge that there is no perfect organization. Everyone can work well with if only they will learn to accept strengths and weaknesses of each other, for by ourselves, we sharpen one another. What is important is whole heart commitment and dedication, and not personal gains and self-satisfaction. Serving others, in fact, is the example given to us by our Master Teacher, our Lord Jesus Christ. He Himself understands our weaknesses, so we too should seek on how to serve others and aid them in becoming a better worker.

\section{References}

Atienza, F. T. (2009). Teacher-parent rapport: its effect to the scholastic performance of the grade 2 pupils in selected elementary schools in the district of Los Baños, division of Laguna, s.y. 2007-2008. [Unpublished Master's Thesis].

Caraan, Jr., A. S. (2011). Introduction to Statistics and Probability: Modular Approach. Jose Rizal University Press. Mandaluyong City.

Cohen, J., et.al. (2009). The Challenge of Assessing School Climate. Educational Leadership. Vol. 66 No. 4

Dela Viña, E. P. (2007). The influence of coordination among principal, teachers and parents to the performance of real elementary school, Calamba City, s.y. 2005-2006. [Unpublished Master's Thesis].

DepEd OrderNo. 35, s. 2015. (2015). The Learning Action Cell (LAC) as a K to 12 Basic Education Program, School-Based Continuing Professional Development Strategy for the Improvement of Teaching and Learning. Department of Education. Philippines

Ivancevich, J. M. and Matteson, M. T. (2005). Organizational Behavior and Management, $6^{\text {th }}$ edition. McGraw-Hill/Irwin Publication, New York

Smith, W. R. (May 2012). Culture of Collaboration. The Education Digest. Ann Arbor, Minnesota. pp. 24, 27 